\title{
Kızılay'ın kuruluş dönemi (1877-1878 Osmanlı-Rus Savaşı): Cerrahi girişimler ve çeşitli yaralanmalarda mortalite oranları
}

\author{
The Red Crescent establishment period (1877-1878 Ottoman-Russian War): Mortality \\ rates in surgical interventions and various injuries
}

\author{
Eray Serdar Yurdakul
}

\begin{abstract}
Özet
Amaç: On dokuzuncu yüzyılda anestezi uygulamaları ve bakteriyoloji ile ilgili önemli keşifler yapılmış ve bu ilerlemeler ampütasyon ve savaş cerrahisinde başarılı sonuçlar alınmasının önünü açmıştır. Bu çalışmada bu yüzyılın ikinci yarısında kurulan Kızılay'ın ilk hastanelerinde uygulanan cerrahi ameliyatlar ve çeşitli yaralanmalarda mortalite oranlarının incelenmesi amaçlanmıştır.

Gereç ve yöntem: Araştırma sürecinde Osmanlı Türkçesi, İngilizce ve Fransızca rapor ve arşiv belgeleri incelendi ve elde edilen veriler yaralanma bölgeleri, büyük ameliyatlar ve diğer cerrahi uygulamalara göre gruplandırılarak karşılaştırmalı analizleri yapıldı.

Bulgular: Bir yıla yakın süren savaş döneminde Kızılay hastanelerinde tedavi edilen toplam 39011 kişiden detaylı verilerine ulaşılabilen 12516'sında $(\% 32,08)$ genel mortalite oranları dâhili hastalıklar ve enfeksiyonlar için \%13,75 (913/6638), cerrahi hastalıklar ve yaralanmalar için \%6,04 (355/5878) olarak bulundu. Cerrahi tedavi uygulamaları ile ilgili detaylı verilerine ulaşılabilen 192 hastada mortalite oranları; ampütasyonlarda $\% 24,3$ (17/70), rezeksiyonlarda \%18,2 (8/44), kırık tedavilerinde \%34,1 (14/41), dezartikülasyonlarda \%15,4 (2/13) ve diğer cerrahi girişimlerde \%28,6 (2/7) olarak bulundu.

Sonuç: Osmanlı Rus Savaşı sırasında Türk hekimler farklı ülkelerde eğitim görmüş olan çok sayıda yabancı hekim ile birlikte çalışmış ve kazandıkları deneyimlerle ülkemizde modern tıbbın temellerini atmışlardır. Bu çalışma aseptik cerrahi ve anestezi eşliğinde yapılan cerrahi uygulamaların ülkemizdeki ilk örneklerine ait verileri içermektedir.
\end{abstract}

Anahtar Kelimeler: Ampütasyon, yaralanma, anestezi, aseptik cerrahi.

Yurdakul ES. Kızılay'ın kuruluş dönemi (1877-1878 Osmanlı-Rus Savaşı): Cerrahi girişimler ve çeşitli yaralanmalarda mortalite oranları. Pam Tıp Derg 2019;12:517-526.

\begin{abstract}
Purpose: In the nineteenth century, important discoveries were made about anesthesia applications and bacteriology, and these advances paved the way for successful results in amputation and war surgery. The aim of this study is to investigate the mortality rates of surgical operations and various injuries in the first hospitals of the Red Crescent, established in the second half of this century.

Materials and methods: During the research process, Ottoman Turkish, English and French reports and archives were examined and the data obtained were grouped according to injury sites, major surgeries and other surgical applications and their comparative analyzes were performed.

Results: A total of 39011 people were treated in Red Crescent hospitals during the war period of nearly one year and detailed data were available for $12516(32,08 \%)$ of whom. The overall mortality rates were $13.75 \%$ (913/6638) for internal diseases and infections, and 6.04\% (355/5878) for surgical diseases and injuries. Mortality rates in 192 patients with detailed data on surgical treatment were $24.3 \%(17 / 70)$ in amputations, $18.2 \%(8 / 44)$ in resections, $34.1 \%(14 / 41)$ in fractures, and $15.4 \%(2 / 13)$ in disarticulations and $28.6 \%(2 / 7)$ in other surgical interventions.

Conclusion: During the Ottoman-Russian War, Turkish physicians worked with a large number of foreign physicians who were educated in different countries and laid the foundations of modern medicine in our country with the experiences they gained. This study includes data from the first examples of aseptic surgery and anesthesia-guided surgical procedures in our country.
\end{abstract}

Key Words: Amputation, injury, anesthesia, aseptic surgery.

Yurdakul ES. The Red Crescent establishment period (1877-1878 Ottoman-Russian War): Mortality rates in surgical interventions and various injuries. Pam Med J 2019;12:517-526.

Eray Serdar YURDAKUL, Dr.Öğr.Üye. Sağlık Bilimleri Üniversitesi, Gülhane Tıp Fakültesi, Tıp Tarihi ve Etik Anabilim Dalı Başkanlığı, ANKARA, e-posta: erayserdar.yurdakul@sbu.edu.tr (orcid.org/0000-0000-0003-0556-393X) 


\section{Giriş}

On dokuzuncu yüzyılda tıp alanındaki önemli gelişmeler arasında öne çıkanlar anestezinin doğuşu, antiseptik cerrahi ve bakteriyoloji bilimindeki keşifler olmuştur [1, 2]. 1877-1878 Osmanlı-Rus Savaşı, bilimsel gelişmelerin ve dönüşümün Kızılay'ın kuruluşu ve uluslararası alanda kabul gördüğü dönemde gerçekleşmiştir [3-6]. Çatışmalar esnasında yaralı askerlere tarafsız olarak yardım etmek amacıyla 1863 yılında kurulan Kızılhaç ile aynı görevi üstlenmek üzere 1868 tarihinde Osmanlı Devleti tarafından "Mecruhin ve Mardayı Askeriyeye İmdat ve Muavenet Cemiyeti" adıyla bir yardım teşkilatı kurulmuş ve bu kurum 1877 tarihinde "Osmanlı Hilâl-ı Ahmer Cemiyeti" adı ile yeniden organize edilerek günümüzdeki Türk Kızılayı'nın çekirdeğini oluşturmuştur [3-5, 7].

Modern anestezinin ilk inhalasyon anestezikleri olan nitröz oksit ve dietil eter ilk olarak dental girişimlerde kullanılmıştır. Horace Wells, 1842 yılında Conneticut'taki bir halk gösterisinde, nitröz oksitin hipnotik ve analjezik etkisini fark etmiş ve sonraki yıllarda ağrılı dental girişimlerde bu maddeyi hastalarında anestezi amaçlı kullanmıştır [8]. Amerikalı bir diş hekimi olan ve aynı zamanda tıp eğitimi de alan William Morton, çok ağrılı bir operasyonu hocaları ve öğrenciler huzurunda hastayı eter ile uyutarak, hastaya acı hissettirmeden başarılı biçimde gerçekleştirmiş ve bu denemenin yapıldığı 10 Ekim 1846 tarihi anestezinin başlangıcı olarak kabul görmüştür [8]. Sonraki yıllarda eter askeri cerrahide de kullanılmıştır. Amerikalı hekim Samuel Guthrie tarafından 1831 yılında keşfedilen kloroform 1847 yılına kadar anestezik olarak kullanılmamıştır [1]. Avrupa'da ise kloroform 1848 Özgürlük Hareketleri sırasında, 1850 Danimarka-Prusya savaşında ve 18531856 Kırım Savaşı'nda hekimler tarafından anestezik olarak kullanılmıştır [9]. İstanbul'da yayınlanmakta olan Journal de Constantinople dergisine göre 1847-1848 yıllarında Galatasaray'daki Mekteb-i Tıbbiye-i Şahane'de yapılan ameliyatlarda kloroform kullanıldığı ve bunun ülkemizde ilk kullanılan anestetik madde olduğu bilgisi yer almaktadır [10]. Anestezi uygulamalarının en önemli avantajı hastanın acı çekmemesi sayesinde, hekimin cerrahiyi yavaş ve dikkatli bir şekilde yapabilmesine olanak sağlamasıydı. Ayrıca ampütasyonlarda daha sonra işe yarayacak olan proteze yönelik güdük oluşumu da sağlıklı olarak yapılabiliyordu
[1]. On dokuzuncu yüzyılda salgın hastalıklarla mücadeledeki başarılı uygulamalar, hastane tıbbı kavramının ortaya çıkışı, asepsiantisepsi uygulamalarındaki gelişmeler ile cerrahi uygulamalar ve sonrasında gelişen komplikasyonlarla ilişkili ölüm oranları da önemli oranlarda azalmıştır [2].

Bu makalede Kızılay tarafından kurulan ilk sağılk teşekküllerinde uygulanan ameliyatlar, çeşitli cerrahi girişimler ve yaralanmalarla ilişkili mortalite oranlarının belirlenmesi ve savaş koşulları ve sosyokültürel durumun ve ayrıca asepsi-antisepsi uygulamalarındaki gelişmelerin ve anestezi tekniklerinin cerrahi uygulamalar ve mortalite oranları üzerine olan etkilerinin incelenmesi amaçlanmıştır. Türkiye'de ortopedinin tarihçesi 1900'lü yılların başlarında eğitim için Osmanlı Hükumeti tarafından Avrupa'ya (başta Almanya ve Fransa olmak üzere) gönderilen hekimlerden başlanarak ele alınmıştır [11]. 1843'lerden itibaren ülkemizde tıp fakültelerinin kurulması ve değişik zamanlarda yurtdışından hocalar getirilmesi gibi gayretlere rağmen cerrah yetişmesinde sıkıntılar yaşanmıştır [12]. Cerrah yetişememesi üzerine, o zamanki hükümet, 1875 de askeri tıbbiyeden çıkan genç doktorlar arasından imtihanla bir hekimi (Naim Efendi) Viyana'ya ve üç hekimi (Cemil Ziya Bey, Hayrettin ve Osman Efendiler) Paris'e göndermiştir. Bu ilk hekimler yurda döndüklerinde 1877'de Osmanlı-Rus harbi başlamış ve bu genç cerrahlar harp sahasına gönderilmişlerdir [12]. Bu makalede sunulan verilerinin Türk ortopedi ve cerrahi tarihinin günümüz sistematiğine uygun olarak düzenlenmiş ilk kayıtları olması nedeniyle özel önem taşıdığını düşünüyoruz.

\section{Gereç ve yöntem}

Bu çalışmanın verileri 1877-1878 OsmanlıRus Savaşında (93 Harbi) Türk Ordularında Askeri Sağlık Hizmetleri'nin araştırıldığı bir doktora tezinden elde edilmiştir [13]. Çalışmada Kızılay tarafından kurulan ilk hastanelerin (27 ayrı hastane) kayıtlarında yer alan cerrahi girişimlerle ilgili veriler metaanaliz prensibi ile birleştirilerek karşılaştırılmıştır.

\section{Araştırma verilerinin toplanması}

$\mathrm{Bu}$ araştırmada arşiv belgeleri, dönemde yayımlanmış kitaplar, raporlar ve süreli yayınlar gibi dönemin birincil kayıtlarına ulaşımış ve incelenmiştir. İlk aşamada savaşlarla ilgili 
arşivlerinin tasnif edildiği Genelkurmay Askerî Tarih ve Stratejik Etüt Daire Başkanlığı (ATASE) Arşivi'nde Osmanlı-Rus Harbi (ORH) katalog taramalarında araştırmanın konusu olan sağlık hizmetleriyle ilgili araştırmaya katkısı olacak 300 belgeye ulaşıldı ve bunlar detaylı olarak incelendi. İkinci olarak, Başbakanlık Devlet Arşivleri Genel Müdürlüğü Osmanlı Arşivi (BOA) kataloglarında bulunan 12 belge incelendi. Son olarak, Kızılay Arşivi'nde yapılan araştırmada mevcut arşivin araştırma ile ilgili tarihî dönemi kapsamadığı tespit edildi. Arşiv belgelerinde Osmanlı-Rus Savaşı süresince Osmanlı Hükümeti'ne bağlı askeri hastaneler ve seyyar hastanelerce (43'ü taşrada 27'si İstanbul'da olmak üzere toplam 70 hastane) sağlık hizmetlerinin yürütülmesi ile ilgili yazışmalar bulunsa da [14-16], bu hastanelerce hazırlanan bir rapora ulaşılamadı.

Arşiv belgeleri dışında savaş dönemine ait sağlık hizmeti sunan kurumlarca hazırlanan raporlar incelendi. Ulaşılabilen en önemli kaynak dönemin Kızılay'ı olan Mecruhin ve Mardayı Askeriyeye Imdat ve Muavenet Cemiyeti'nin 1878 yılında (savaşın hemen sonrasında) yayımladığı Fransızca rapordur [17]. Bir diğer önemli kaynak ise İngiliz hükûmetinin teşvikiyle kurulan "Stafford House Komitesi (SHK) Hasta ve Yaralı Türk Askerlerine Yardım Cemiyeti" tarafından 1879 yılında yayımlanan İngilizce rapordur [18]. Bu raporlar savaş sürecinde yürütülen sağlık hizmetlerine dair mortalite ve morbidite oranları ve bulaşıcı hastalıklar gibi sorunlar ve bu sorunlarla ilgili alınan önlemler gibi önemli bilgileri ve istatistikleri de içeren resmi kayıtlardır. Her iki kaynağın çevirisi yapıldı ve çalışma başıı̆ında belirtilen detaylar yönünden incelendi. Stafford House Komitesi Raporu'nda hastalık tipi ve yaralanma bölgelerine göre mortalite oranlarını gösterir ayrıntılı bilgiler bulunmadığı için, bu çalışma başlıca 1877-1878 Osmanlı Rus Savaşı'nda Kızılay tarafından kurulan hastanelerde (27 ayrı hastane) yürütülen sağılk hizmetlerine dair verileri kapsamaktadır (Şekil 1).

\section{Incelenen parametreler ve karşılaştırmalar}

Kızılay tarafından kurulan 27 ayrı hastanenin verileri aşağıdaki algoritma (Şekil 2) izlenerek incelendi ve bu hastanelere ait ulaşılabilir verileri içeren ortak tablolar oluşturuldu. Farklı hastane kayıtlarında yaralanma bölgesi veya ameliyatlar için çok sayıda farklı alt grup ve tanımlama olduğu belirlendi. Bu verilerin tek bir tabloda gösterilebilmesi için gruplandırmalar yapıldı ve farkı hastanelere ait aynı kategorideki tüm veriler tek bir tablo satıında gösterilecek şekilde birleştirildi. Yaralanma bölgeleri ve hastalıklar için 18 farklı hastanenin kayıtları incelenerek toplam 14 bölge-grup oluşturuldu (bulgular bölümü Tablo 2'ye bakınız). Büyük ameliyatlar ve diğer cerrahi girişimler ise altı farklı ameliyat-cerrahi girişim için 16 ayrı

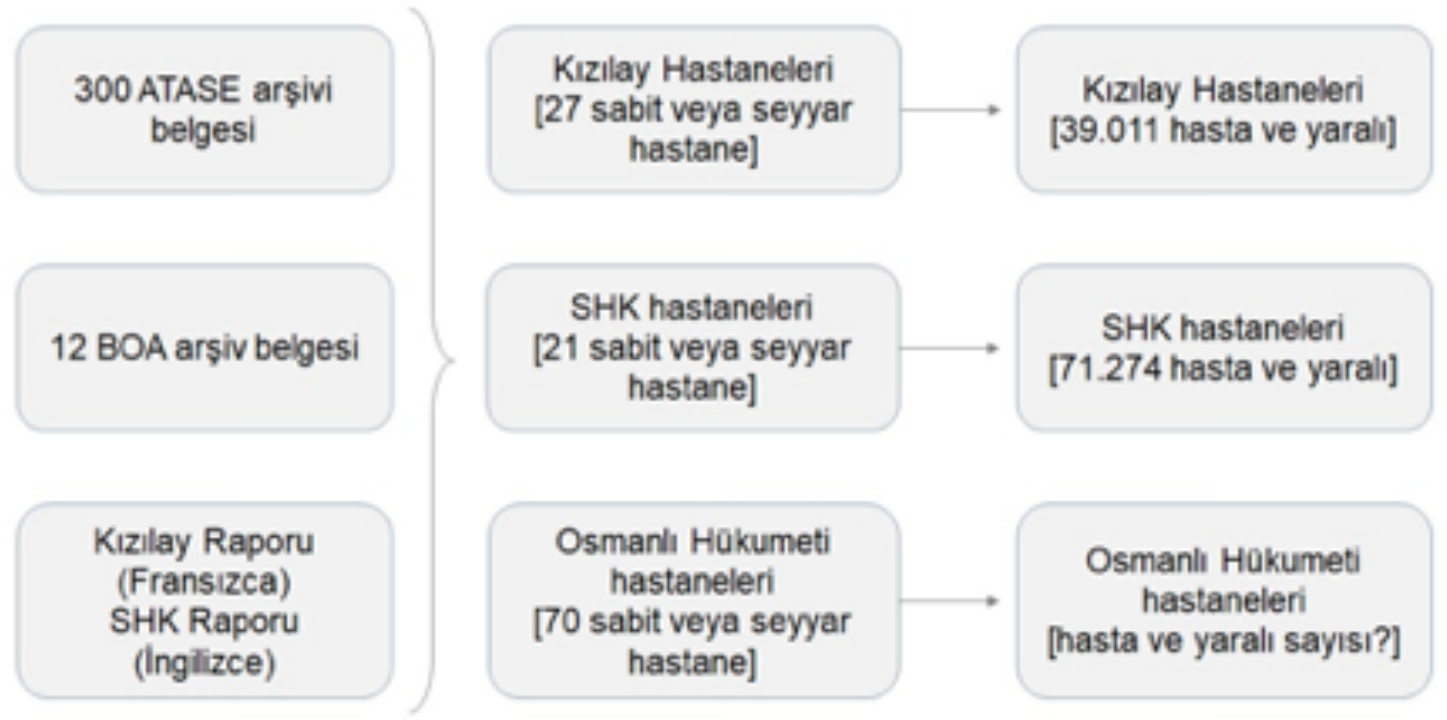

Şekil 1. Arşiv belgelerinin taranması ve çalışmaya dahil edilecek hastanelerin belirlenmesinde kullanılan akış şeması. 


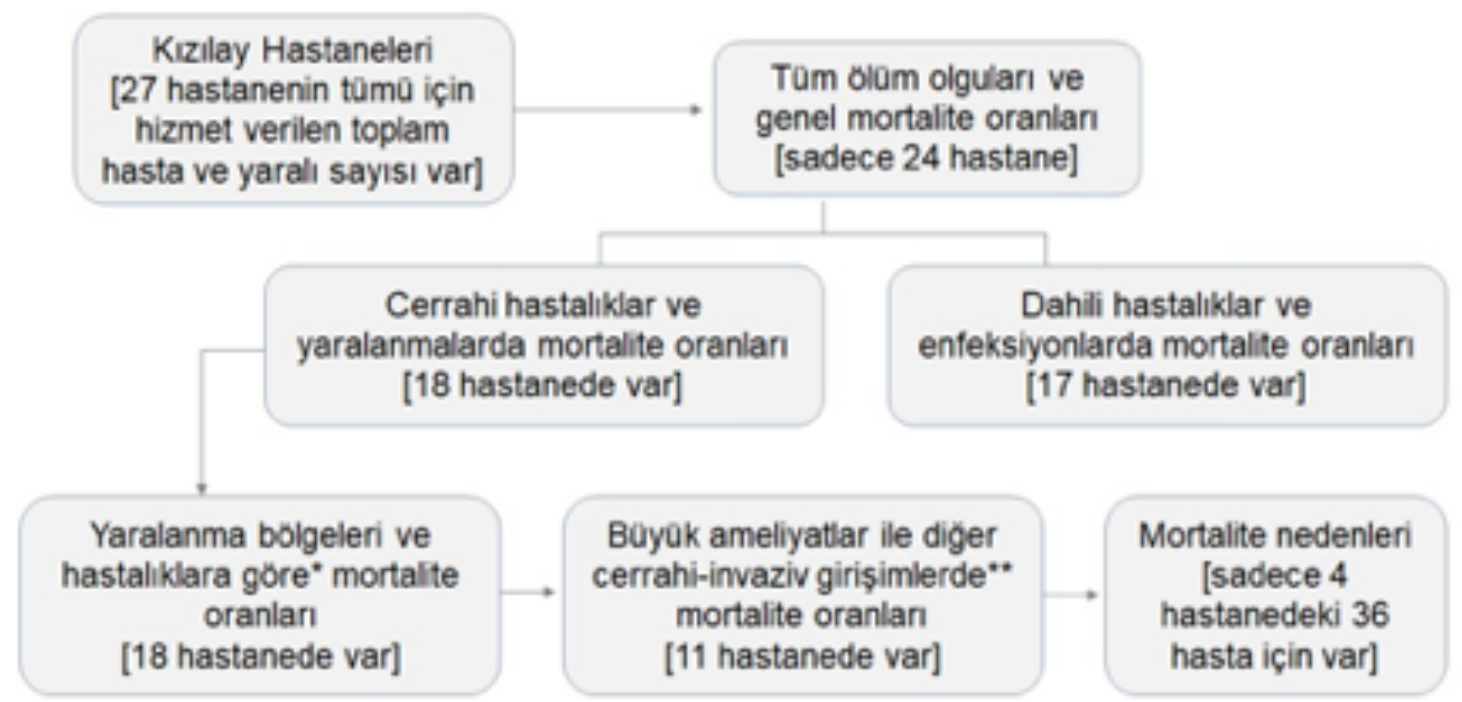

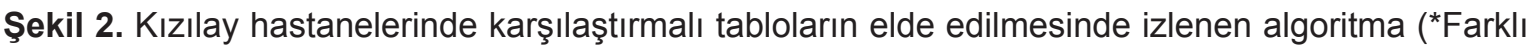
hastane verileri 14 farklı anatomik bölge oluşturularak birleştirildi. ${ }^{* *}$ Farklı hastane verileri 6 farklı ameliyat-cerrahi girişim türü için 16 farklı anatomik bölge oluşturularak birleştirildi).

bölge-grup oluşturularak ve hastane verileri birleştirilerek incelendi (bulgular bölümü Tablo 3'e bakınız). Son olarak kategoriler için mortalite oranları hesaplanarak veriler yüzdesel olarak karşılaştırıldı.

Büyük ameliyatlar ve diğer cerrahi girişimler için hastalar şu şekilde gruplandırıldı:

1. Ampütasyonlar: Hasar gören kol, bacak, el, ayak ve parmakların, ilgili uzvun kemiği ile beraber kesilerek vücuttan ayırıldığı cerrahi işlemlerin uygulandığı hastalar.

2. Dezartikülasyonlar: Eklem seviyesinden yapılan ampütasyon uygulamaları.

3. Rezeksiyonlar: Kanlanması bozulmuş veya enfekte olmuş kemik veya dokuların bir bülümünün (parsiyel rezeksiyon) veya tamamının (komplet rezeksiyon) kesilerek çıkarıldığı cerrahi işlemler.

4. Sekestrektomi ve drenaj uygulamaları: Çürüme-nekroz gelişmiş kemik parçalarının veya abse formasyonu görülen kemik-eklem dokularının kesilerek çıkarıldığı ve/veya pansuman uygulamaları ile (basit pansuman, Guérin pansumanı, fenol pansumanı gibi) tedavi edildiği hastalar.

5. Kırık tedavileri: Ateşli silah yaralanmaları, künt travmalar veya yüksekten düşme gibi nedenlerle kemik kırıkları oluşan ve bandaj, basit atel, atel cihazı, Clyne tipi yastıklı ateller ile tedavi edilen hastalar.

6. Diğer girişimler: Kist-polip eksizyonu, mesane taşı nedeniyle median kesi, perianal fistül, batın, torakal ve lomber bölge ile ilgili özel cerrahi girişimler.

\section{Bulgular}

Kızılay savaş süresince 8'i muhacirler için olmak üzere 12'si İstanbul'da, 9'u seyyar olmak üzere 15 'i taşrada (cephe ve cephe gerisinde) toplam 27 hastane kurmuştur [17]. Bu hastaneler Kızılay'ın ilk sağlık teşekkülleri olup, bazıları sabit hastaneler iken, bir bölümü de cephe hattının hemen gerisinde kurulan ve asıl görevi ilk müdahale ve yaralı tahliyesi olan geçici sağlık teşekkülleridir (Tablo 1).

Osmanlı Hilâl-i Ahmer Cemiyeti tarafından tesis edilen sabit ve seyyar hastanelerde 1 Ağustos 1877 tarihinden 30 Haziran 1878 tarihine kadar, 25.115 yaralı ve 13.896 hasta olmak üzere toplam 39.011 kişi hizmet almıştır. Tedavi gören yaralı ve hastaların hastanelere göre dağılımı ve toplam sayıları ile hastanelere göre mortalite oranları Tablo 1'de görülmektedir. Hastane kayıtları ayrı ayrı incelendiğinde tedavi edilen hasta ve yaralının yaklaşık üçte biri için $(12516 / 39.011 ; \% 32,08)$ hastalık ve yaralanma tipi ve ilişkili mortalite oranlarına dair detaylı 
Tablo 1. Hilâl-ı Ahmer Cemiyeti (Kızılay) tarafından tesis edilen sağlık teşekküllerinde tedavi gören yaralı ve hasta dökümü ile mortalite oranları [12].

\section{Hastane}

\section{Başkentteki Sabit Hastaneler}

2. Beylerbeyi Hastanesi: Paşa Dairesi

3. Beylerbeyi Hastanesi: Musiki Dairesi

4. Beylerbeyi Hastanesi: Ağalar Dairesi

\section{Başkentteki Sabit Mülteci Hastaneleri}

5. Gülhane Hastanesi

6. Çinili Köşk 1 Numaralı Baraka Hastanesi

7. Paşabahçe Hastanesi

8. Şemsi Paşa Hastanesi (Üsküdar)

9. Nakilbend ve Tunuslu Hastanesi (Üsküdar)

10. Kumbarhane Hastanesi

11. Sirkeci İskelesi Kadın Mülteci Hastanesi

12. Takiyeddin Paşa Hastanesi

\section{Taşradaki Sabit-Geçici Hastaneler}

13. Varna Geçici Hastanesi

14. Varna Türk-Mısır Geçici Hastanesi

15. Edirne Askeri İdadiye Geçici Hastanesi

16. Edirne Askeri Belediye Geçici Hastanesi

17. Selanik Hastanesi (Islahane-Dr. Lebovicz)

18. Selanik Hastanesi (Islahane-Dr. Weber)

\section{Seyyar Hastaneler}

19. Stoker Hastanesi (Tahliye servisi)

20. Sivastopol ve Dallas Hastanesi (Şıpka)

21. Goldstein Hastanesi (Orhaniye - Kazanlık)

22. Heinrich Hastanesi (Razgırat)

23. Sarell Hastanesi (Orhaniye, Kemerli,

Taşkesen, Sofya)

24. Roy Hastanesi (Erzurum)

25. Cuma Dr. Antoniades Hastanesi

- Cuma Hastanesi (Yaralı Tahliye Servisi)

26. Dr. Colonna Ceccaldi Sağlık Treni

27. Sirkeci Dr. Mundy ve Dr. Mautner Hastanesi

Toplam
1. Kavak Hastanesi

$\begin{array}{ll}\text { Tüm } & \text { Tüm ölüm } \\ \text { hastalar } & \text { olguları ve } \\ & \text { genel mortalite }\end{array}$

490

(6)

2606

$18(3,67)$

$285(10,94)$

831

$56(6,74)$

$12(3,68)$

$74(25,34)$

$54(25,47)$

212

$32(19,28)$

750

$184(24,53)$

$40 \quad 0$

$585 \quad 110(19,0)$

80 Veri yok

297

$49(16,5)$

$43(3,75)$

$19(3,63)$

$11(3,93)$

$7(5,0)$

0

\begin{tabular}{llll}
2167 & Veri yok & Veri yok & Veri yok \\
2268 & $114(5,03)$ & $20 / 60(3,33)$ & $94 / 2208(4,26)$ \\
4008 & Veri yok & Veri yok & $16 / 40(40,0)^{*}$ \\
465 & Veri yok & Veri yok & Veri yok \\
6514 & $190(2,92)$ & Veri yok & Veri yok \\
2251 & $295(13,11)$ & $220 / 1703(12,92)$ & $75 / 548(13,67)$ \\
287 & $17(5,92)$ & $17 / 256(6,64)$ & $0 / 31$ \\
1650 & Veri yok & Veri yok & Veri yok \\
1427 & $15(1,05)$ & Veri yok & Veri yok \\
9149 & $21(0,23)$ & Veri yok & Veri yok \\
39011 & $\begin{array}{l}1606 / 30641 \\
(\% 5,24)\end{array}$ & $\begin{array}{l}913 / 6638 \\
(\% 13,75)\end{array}$ & $\begin{array}{l}355 / 5878 \\
(\% 6,04)\end{array}$ \\
\hline
\end{tabular}

* Kızılay raporunun bu hastaneye ait bölümünde sadece 40 hasta ile ilgili detaylı bilgi sunulmuş olup bu hastalar genel toplama dahil edilmiştir, raporda diğer hastalara dair bir veri bulunmamaktadır.

$\begin{array}{ll}\text { Dâhili } & \text { Cerrahi } \\ \text { hastalıklar ve } & \text { hastalıklar ve } \\ \text { ölüm oranları } & \text { ölüm oranları } \\ (\%) & (\%)\end{array}$

Veri yok

Veri yok

$219 / 1486(14,74) \quad 66 / 1120(5,89)$

$45 / 556(8,09)$

$11 / 275(4,0)$

$\begin{array}{ll}12 / 283(4,24) & 0 / 43 \\ 73 / 284(25,7) & 1 / 8(12,5) \\ 54 / 212(25,47) & 0 / 0 \\ 32 / 156(20,51) & 0 / 10 \\ 181 / 692(26,16) & 3 / 58(5,17) \\ 0 / 39 & 0 / 1 \\ \text { Veri yok } & \text { Veri yok } \\ \text { Veri yok } & \text { Veri yok }\end{array}$

$0 / 0$

49/297 (16,5)

$10 / 395(2,53)$

19/481 (3,95)

$5 / 177(2,82)$

6/131 $(4,58)$

$0 / 55$

$\begin{array}{ll}1 / 9(11,11) & \\ 0 / 4 & 0 / 55\end{array}$


verilere ulaşıldı. Bunların 6638'i enfeksiyonlar ve çeşitli dâhili hastalıklar nedeniyle tedavi edilen kişiler olup, bu hastalarda genel mortalite oranı \%13,75 olarak bulundu (Tablo 1). Diğer 5878 kişi ise cerrahi hastalıklar ve yaralanmaları olan hastalardı, bu grupta ise genel mortalite oranı \%6,04 olarak bulundu. Kızılay Hastanelerinde uygulanan cerrahi girişimler ve çeşitli yaralanmalarda mortalite oranlarını ortaya koyabilmek adına söz konusu 5878 hastanın detaylı verileri ile oluşturulan Tablo 2'de yaralanma bölgeleri ve hastalıklara göre sayısal dağılım ve ölüm oranları görülmektedir.

Kızılay hastanelerinde yatarak tedavi gören 192 hasta ve yaralı için cerrahi hastalıklar ve yaralanmalar ve bu hastalıkların tedavileri sırasında ortaya çıkan komplikasyonlara dair daha detaylı kayıtların tutulduğu belirlendi. $\mathrm{Bu}$ hastalar ile ilgili ayrıntılı veriler Tablo 3'te sunulmuştur.

Tablo 2. Yaralanma bölgeleri ve hastalıklara göre sayısal dağılım ve ölüm oranları*.

\begin{tabular}{lllll}
\hline & $\begin{array}{l}\text { Taburcu } \\
\text { edilen }\end{array}$ & Tedavi altında & Ölen & Toplam \\
\hline Baş ve boyun yaralanmaları & 115 & 45 & $3(\% 1,84)$ & 163 \\
Göğüs ve Gövde yaralanmaları & 157 & 48 & $13(\% 5,96)$ & 218 \\
Omuz yaralanmaları & 26 & 13 & $3(\% 7,14)$ & 42 \\
Üst ekstremite (kol-önkol) yaralanmaları & 486 & 127 & $13(\% 2,08)$ & 626 \\
El yaralanmaları & 187 & 37 & $5(\% 2,18)$ & 229 \\
Kalça yaralanmaları & 77 & 43 & $3(\% 2,44)$ & 123 \\
Alt ekstremite (bacak ve uyluk) yaralanmaları & 334 & 206 & $21(\% 3,74)$ & 561 \\
Ayak yaralanmaları & 49 & 24 & $3(\% 3,95)$ & 76 \\
Ateşli silaha bağlı basit yaralanmalar & 702 & 136 & $0(\% 0)$ & 838 \\
Kesici delici alet yaralanmaları & 185 & 21 & $16(\% 7,21)$ & 222 \\
Ekstremite ve ayaklarda donma ve kangren & 343 & 86 & $58(\% 11,91)$ & 487 \\
Yanık & 11 & 7 & $0(\% 0)$ & 18 \\
Çeşitli cerrahi hastalıklar ve komplikasyonlar & 110 & 50 & $54(\% 25,23)$ & 214 \\
Diğer yaralanmalar & 1496 & 402 & $163(\% 7,91)$ & 2061 \\
Cerrahi kliniği genel toplam & $\mathbf{4 2 7 8}$ & $\mathbf{1 2 4 5}$ & $\mathbf{3 5 5}(\% \mathbf{6 , 0 4 )}$ & $\mathbf{5 8 7 8}$ \\
Enfeksiyonlar ve çeşitli dâhili hastalıklar & 4240 & 1485 & $913(\% 13,75)$ & 6638 \\
Toplam & $\mathbf{8 5 1 8}$ & $\mathbf{2 7 3 0}$ & $\mathbf{1 2 6 8}(\% \mathbf{1 0 , 1 3 )}$ & $\mathbf{1 2 5 1 6}$ \\
\hline
\end{tabular}

*Bu tablo detaylı kayıtların tutulduğu hastane raporlarının birleştirilmesiyle oluşturulmuştur ve Kızılay hastanelerinde tedavi gören hasta ve yaralıların yaklaşık üçte birini $(\% 32,08)$ temsil etmektedir.

Kızılay raporlarında Tablo 3'te yer alan 43 ölüm olgusunun 36'sında ölüm nedeni belirtilmişken, yedi olguda ölüm nedenleri ile ilgili bir bilgiye ulaşılamamıştır. Raporlanan Ölüm nedenlerinin sayısal dağılımı şu şekildedir; piyemi ve pürülan enfeksiyonlar 16 , pnömoni beş, peritonit bir, diğer enfeksiyonlar (diyare, dizanteri, tifüs, tetanoz ve tüberküloz) yedi olmak üzere enfeksiyonlarla ilişkili toplam 29 ölüm, ampütasyon reddi ile ilişkili dört ölüm (üçü ilk yatışta ampütasyonu reddetme, biri ikinci ampütasyonu reddetme), anemi ile ilişkili iki ölüm ve sekonder kanama ile ilişkili bir ölüm olgusu.

Bazı hastanelerde yapılan cerrahi işlemler genel sayılarla ifade edilmişken, bazı hastanelerde ise bölgelere göre toplam sayılar ifade edilmiş, fakat ölüm oranları belirtilmemiştir. Roy Hastanesi'nde (Erzurum) yapılan cerrahi işlemler ile ilgili kayıtlar ikinci duruma bir örnek teşkil etmektedir (Tablo 4). Bu şekilde tutulan kayıtlarda cerrahi girişimlere göre mortalite oranları belirlenemediği için bu veriler yukarıdaki tabloya (Tablo 3) dahil edilmemiştir.

Kızılay'ın sağlık teşekküllerinde sadece Türk askerleri ve mültecilere sağlık hizmeti verilmemiş, bazı hastanelerde Rus askerleri de tedavi edilmiştir. Örneğin 2 Numaralı Seyyar Hastane (Sivastopol ve Dallas Hastanesi; Şıpka) kayıtlarında “7, 8, 9 Ocak 1878'de üç gün süren savaş sırasında seyyar hastane, 85'i Rus olan 1278 yaralıyı kabul ederek bakımını yaptı" ifadesi yer almaktadır [17]. 


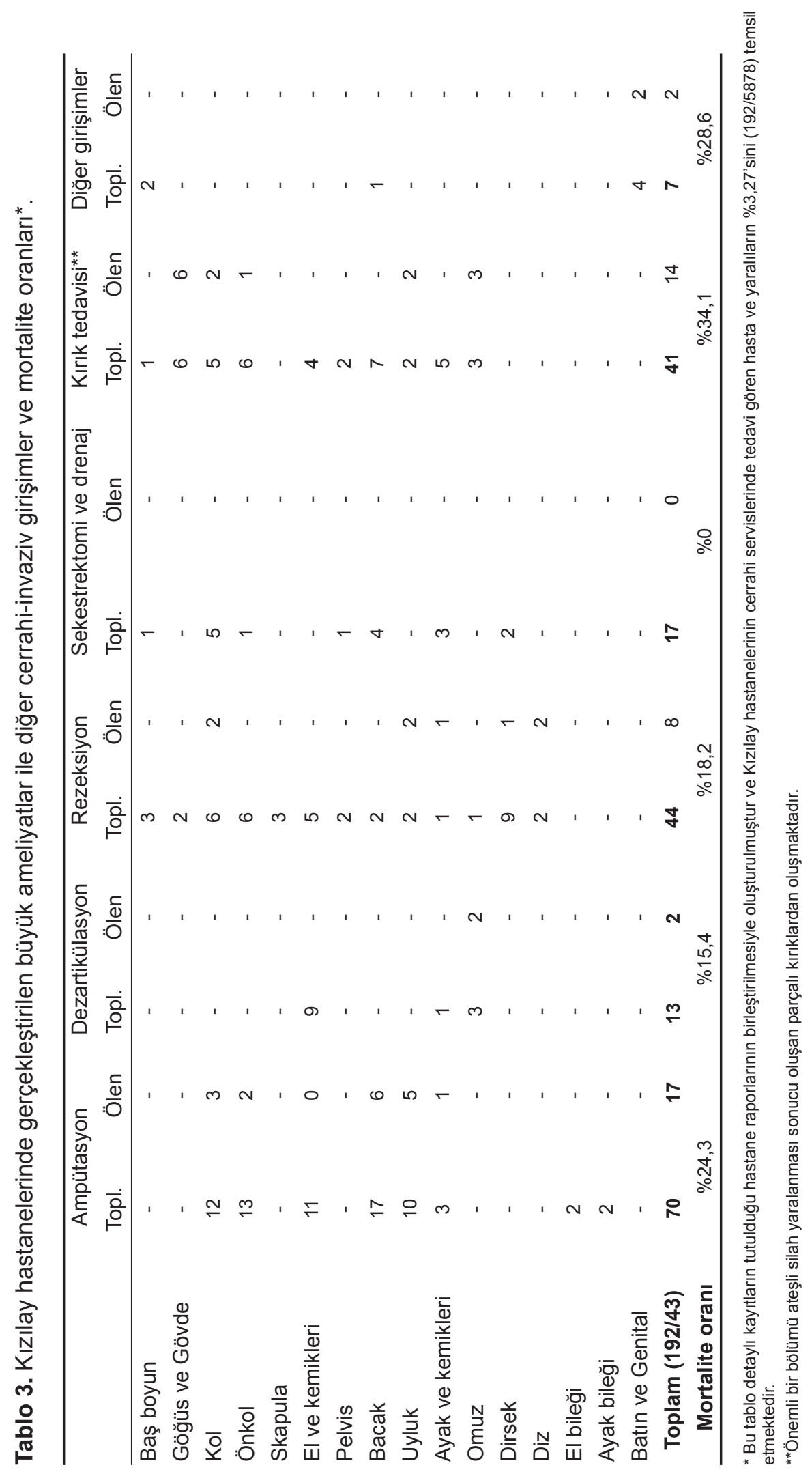


Tablo 4. Erzurum Hastanesi'nde (Roy Hastanesi) yapılan ana cerrahi işlemler 17 Şubat-30 Nisan 1878 [12].

\begin{tabular}{lclc}
\hline Yaralanmaların Cinsi & Sayı & Ameliyatlar & Sayı \\
\hline & 12 & Kol ampütasyonu & \\
& 8 & Önol ampütasyonu & \\
& 19 & Bilek dezartikülasyonu & 72 \\
Obüs patlaması, mermi ve kesici aletle & 26 & Parmak dezartikülasyonu & \\
yaralanmalar & 4 & Uyluk ampütasyonu & \\
& 2 & Humerus dezartikülasyonu & 45 \\
& 1 & Orta parmak ve yüzük parmağı dezartikülasyonu & \\
& 16 & Bilek ampütasyonu & \\
& 1 & 3 ayak parmağının dezartikülasyonu & \\
& 1 & 2 ayak parmağının dezartikülasyonu & \\
& 2 & Ayak dezartikülasyonu & Toplam \\
& 25 & Çeşitli kangren ameliyatları & \\
\hline
\end{tabular}

\section{Tartışma}

Savaşlar tarih boyunca tıbbi uygulamaların gelişmesinde önemli rol oynamıştır. Örneğin, Amerikan İç Savaşı (1861-1865) sırasında tıp alanında çok sayıda önemli ilerleme gerçekleşmiştir [19]. Bu savaşı diğerlerinden ayıran en önemli özellik sanayi devriminin üretken kapasitesi ile askeri gücün entegrasyonunun tamamlandığı süreçteki ilk modern savaş olmasıdır. Bu savaşta tarihteki en büyük çatışmalar olmuş ve öngörülerin çok ötesinde ateşli silah yaralanması ve insan kayıpları meydana gelmiştir [19]. Anestezi, primer ampütasyon, atel ve nekrotik doku debridmanı gibi yara tedavisinde kullanılan etkili yöntemler bu savaşın yaygın uygulamaları olmuştur [1]. Bu savaşın sonlanmasından on iki yıl kadar sonra başlayan Osmanlı Rus harbinde ise yeni gelişmelerin ve teknik ilerlemelerin de katkısı ile tıbbi uygulamaların daha ileri örnekleri sunulmuştur.

Savaş yaralanmaları ve cerrahi uygulamaların başarısını artıran ikinci önemli etken ise asepsi ve antisepsinin gelişimidir [2]. Pansuman malzemelerini karbolik asit (fenol) ile yıkayarak yara üzerine uygulayan Joseph Lister'in 1866 yılındaki uygulamaları bu konudaki ilk örneklerdir. Lister kendi cerrahi kliniğinde uyguladığı bu yöntem ile cerrahi sonrası mortalite oranını \%45'ten \%1,5'lara kadar düşürmüş ve bu pansuman metodu savaşlarda da kullanılmaya başlamıştır [1]. Osmanlı Rus savaşında gerek cephe hattının gerisinde, gerekse hastanelerde yara bakımı ve pansuman uygulamaları görevli hekimlerce veya onların gözetimindeki yardımcı sağlık personeli tarafından yaygın olarak gerçekleştirilen bir uygulama olmuştur [20].

Tarih boyunca savaşlar sırasında hastalıklardan ve enfeksiyonlardan ölenlerin sayısı silahla yaralanarak ölenlerden çok daha fazla olmuştur [20]. 1877-1878 Osmanlı Rus savaşında Ruslar 88.000'den fazla insan kaybetmiştir. Şöyle ki, Rus Tuna Ordusu'nda 5096 yaralanma ve 45.828 hastalık ilişkili ölüm olduğu tahmin edilirken, Kafkas Ordusu'nda 1869 yaralanmaya karşın ve 35.311 hastalıktan ölüm gerçekleşmiştir, hastalıktan ölümler yaralanmalardan ölümlerle kıyaslandığında batı ve doğu cephelerinde sırasıyla 9 ve 18 kat daha fazla olmuştur [21]. Bu yüksek oranların en önemli nedenleri dizanteri, tifüs, pnömoni, gastroenterit, bronşit ve akciğer tüberkülozu gibi enfeksiyonlardır [20]. 18771878 Osmanlı Rus harbi döneminde Kızılay hastanelerinde bir yıla yakın sürede toplam 39.011 hasta ve yaralı tedavi edilmiştir. Kızılay hastanelerinde tedavi gören hasta ve yaralılar arasında toplam ölüm olgusu sayısı kayıtlarına ulaşılabilen 30641 hastada 1606 'dır $(\% 5,24)$. Bu hastaların 12.516'sına $(\% 32,08)$ ait detaylı verilere göre ise dahili ve cerrahi hastalıklarda mortalite oranları sırasıyla $\% 13,75$ ve $\% 6,04$ olarak bulundu (Tablo 1). Dahili hastalıklardan ölümlerin en önemli nedeni enfeksiyon hastalıkları ve salgınlara bağlı ölümlerdi (Tablo 1). Bu veriler hastane tıbbı kavramının 
önemini açık bir şekilde ortaya koymaktadır. Şöyle ki Rus Ordusu için bakıldığında 9 ila 18 kat olan fark, hastanede tedavi imkanı bulan kişilerde iki kat gibi çok daha düşük oranlara inmiştir. Bu düşüşte yara bakımı ve pansuman uygulamaları, sanitasyon ve hijyen önlemleri şüphesiz en önemli etkenler olmuştur. Bununla beraber, savaş koşullarının getirdiği güçlükler yüksek sayılarda hasta kabulü ve tahliyesinin kısa bir zaman dilimi içerisinde gerçekleştirildiği bazı hastanelerde (özellikle cephe hattına yakın seyyar hastaneler ve göç hareketleri ile aşırı hasta yükünün görüldüğü mülteci hastaneleri) bu koruyucu sağlık uygulamaları yetersiz kalmış ve detaylı hasta kayıtlarının tutulması mümkün olmamıştır. Stoker Hastanesi (Tahliye servisi) ile ilgili Kızılay raporunda [17] yer alan şu ifadeler bu durumu ortaya koyan bir örnek niteliğindedir: "Seyyar hastanenin hareketliliği ve sürekli yer değiştirmesi, doktorlara sadece bazı cerrahi girişimleri yapılabilmeleri için olanak sağlıyordu. $\mathrm{Bu}$ doktorlarca sadece dokuz ampütasyon yapılabilmiştir. Olguları hastaneye ulaştırma ve sürekli seyahat etme zorunlulukları nedeniyle, yaptıkları cerrahi işlemleri kaydedememişlerdir". Tüm bu olumsuzluklara rağmen bazı hastanelerde yapılan ameliyatlar ve hasta takiplerine ait detaylı kayıtlar tutulmuş ve bu raporlar günümüze kadar ulaşmıştır.

Büyük ameliyatlar ve diğer cerrahi-invaziv girişimler ile ilgili detaylı verilerine ulaşılabilen 192 hastada en çok uygulanan cerrahi girişimin ampütasyonlar olduğu görülmektedir. Kayıtlara göre ampütasyonlarda genel mortalite oranı \%24,3 (17/70) olarak bulundu. Ampütasyonlar ve dezartikülasyonlar bilinen en eski cerrahi işlemlerdendir, bununla beraber Kızılay hastanelerinde Lisfranc ampütasyonu, Chopart dezartikülasyonu, Pirogoff ampütasyonu gibi teknik ayrıntıları tanımlanmış birçok farklı ameliyat yapılmıştır [17]. Sık gerçekleştirilen diğer tedavi uygulamalarından rezeksiyonlar ve kırık tedavilerinde ise mortalite oranları sırasıly \%18,2 (8/44) ve \%34,1 (14/41) olarak bulundu (Tablo 3). Kızılay raporunda kırıkların genel olarak parçalı kırık şeklinde olduğu ve ateşli silah yaralanmaları ile birlikteliği bilgisi yer almaktadır. Özellikle göğüs ve gövde bölgesindeki yaralanmalarla birlikte olan kırıklarda ölüm oranının daha yüksek olduğu görülmektedir (Tablo 3). Yaralanma bölgeleri ve hastalıklara göre sayısal dağılım ve ölüm oranlarına bakıldığında (Tablo 2), karşımıza çıkan bir diğer önemli ölüm nedeni de ekstremite ve ayaklarda donma ve kangren olguları idi. Bu hastalarda mortalite oranı \%11,91 (58/487) olarak bulundu. Büyük arterlere yakın olan omuz ve uyluk yaralanmaları veya bu bölgelere yapılan cerrahi müdahalelerdeki ölüm oranlarının diğer bölgelere göre daha yüksek oranlarda olması da dikkat çekmektedir (Tablo 2 ve 3 ).

Az sayıda hastaya ait ulaşılabilir detaylı verilere göre büyük ameliyatlar ile diğer cerrahiinvaziv girişimlerdeki ölümlerin en önemli nedenleri olarak enfeksiyonlar (başta yara yeri enfeksiyonları olmaküzere) ve ampütasyon reddi karşımıza çıkmaktadır. Anestezi uygulamaları savaş yaralanmalarında yaralıların acısını ve cerrahi şoktan ölümleri de anlamlı olarak azaltmış olsa da [1], Kızılay raporlarında tüm yaralıların sayısına bakıldığında gerçekleştirilen ameliyat sayılarının pek az olduğu ve çoğu hastanın ampütasyona izin vermek istemediği bilgisi yer almaktadır. Kızılay [17] ve Stafford House Komitesi raporlarında [18] ampütasyon reddinin en önemli iki nedeni olarak; (i) savaşın ilk zamanlarında diğer cerrahi işlemlerde olduğu gibi ampütasyonların da tecrübesiz cerrahlar tarafından gerçekleştirilmesi ve ayrıca ekipman yetersizliği, operasyonun zamanında yapılamaması gibi sebeplerle ameliyatların ölümle sonuçlanması, (ii) askerlerin kesik bir beden yerine tüm vücutları ile ölmeyi tercih etmeleri yer almaktadır. Bazı hastanelerde ve çatışma bölgelerinde anestezik madde (eter, azot peroksit ve kloroformun) uygulamaları gerçekleştirilememiş ve cerrahi girişimler hasta alkol ile sedatize edilerek uygulanmaya çalışılmıştır. Türk askerlerinin dini inançları gereği alkol ile anesteziyi kabul etmemesi de ampütasyon reddinin diğer bir nedeni olarak belirtilmiştir [18].

Sonuç olarak, Osmanlı Rus Savaşı sırasında gerek Kızılay hastanelerinde gerekse Stafford House Komitesi hastanelerinde farklı ülkelerde eğitim görmüş olan çok sayıda yabancı hekim görev almış ve çok sayıda modern cerrahi uygulamaları gerçekleştirmişlerdir. Bu hekimlerle beraber çalışan Türk hekimler ve yardımcı sağlık personeli hem tıbbi uygulamalar, hem de hasta takibi ve bakımına dair önemli tecrübe ve deneyimler kazanarak ülkemizdeki modern tıbbın temellerini atmışlardır. 
Çıkar İlişkisi: Yazar çıkar ilişkisi olmadığını beyan eder.

\section{Kaynaklar}

1. Gabriel RA, Metz KS. A History of military medicine, Volume 2. Westport, CT: Greenwood Press, 1992;146204.

2. Demirhan Erdemir A, Öncel Ö. Development of asepsis and antisepsis in Turkey in the nineteenth century and its importance from the point of view of Turkish medicine of today and future. T Klin J Med Ethics, Law and History 2002;10:186-190.

3. Karal Akgün S, Uluğtekin M. Hilal-i Ahmer'den Kızılay'a. Ankara: TDV Yayıncilık- Alternatif Ajans, 2002.

4. Hilâl-ı Ahmer alamet-farikasının Grandük Nikola tarafından tanındığı. ATASE Arşivi, ORH Kataloğu, Kutu:26, Gömlek:126, Tarih:10.08.1293 (22 Ekim 1877).

5. Cenevre Mukavelesi gereğince Hilal-ı Ahmer'e de Salib-i Ahmer'e tanınan statünün tanınması. BOA, Fon Kodu:Y.PRK.ASK, Dosya No:1, Gömlek No:33, Tarih: 23/R/1294 (Hicrî).

6. Ataç A, Uçar M, Yiğitler C. Osmanlı hasta ve yaralı askerlere yardım cemiyeti'nin 1877-78 Osmanlı-Rus savaşında yürüttüğü sağlık hizmetleri. İstanbul, 8.Türk Tıp Tarihi Kongre Kitabı, 2006;347-366.

7. Çapa M. Kızılay (Hilâl-i Ahmer) Cemiyeti (1914-1925). Ankara: Türkiye Kızılay Derneği Yayınları, 2010.

8. Karacalar S, Aykaç B. Dental girişimlerde genel anestezi uygulamaları. Marmara Med J 2010;23:400407.

9. Shepherd JA. The smart of the knife-early anesthesia in the services. J R Army Med Corps 1985;131:109115.

10. Akpir K. Türk anestezi tarihi. Türk Anest Rean Der Dergisi 2012;40:1-25. https://dx.doi.org/10.5222/ JTAICS.supp1.2012.001

11. Tanaçan H. Türk ortopedisinin tarihçesi. Acta Orthop Traumatol Turc 1993;27:151-159.

12. Ceylan İ. Batıya yöneliş. Türklerde cerrahinin gelişimi. Türk Cerrahi Derneği Yayınları, Ankara, 2012;66-77.

13. Yurdakul ES. 1877-1878 Osmanlı Rus Savaşında Türk Ordularında Askeri Sağlık Hizmetleri. Gülhane Askeri Tıp Akademisi, Sağlık Bilimleri Enstitüsü, Doktora Tezi (Danışman; Muharrem UÇAR). Ankara, 2015.

14. Edirne, Niş, Vidin fırkalarında seyyar hastane açılması ve bu hastanelere memur ile malzeme temin edilmesi. ATASE Arşivi, ORH Kataloğu, Kutu:112, Gömlek:11, Tarih:29.05.1292.

15. Kadıköy Fırkası'nda bulunan seyyar hastanenin lağv edilip edilmediğinin bildirilmesi. ATASE Arşivi, ORH Kataloğu, Kutu:112, Gömlek:91, Tarih:13.10.1293.
16. Çatalca'da ikamet edecek fırka için teşkil edilecek seyyar hastaneye personel gönderilmesi isteği. ATASE Arşivi, ORH Kataloğu, Kutu:84, Gömlek:26, Tarih:07.11.1293.

17. Hilal-i Ahmer Raporu. Aux Blessés et Malades Militaires-Ambulances Fixes et Mobiles du Croissant Rouge 1877-1878 (Mecruhin ve Mardayı Askeriyeye İmdat ve Muavenet Cemiyeti Sabit ve Seyyar Hastaneleri: 1877-1878), Cilt: 3, İstanbul, 1878.

18. Stafford House Committee for the Relief of Sick and Wounded Turkish Soldiers. Report and record of the operations of the Stafford house committee for the relief of sick and wounded Turkish soldiers: RussoTurkish war, 1877-1878, Spottiswoode\&Co., NewStreet Square, London, 1879:1-180.

19. Brooks SM. Civil war medicine. Illinois: Springfield, 1966.

20. Yurdakul ES. Kızılay'ın ilk hastaneleri (1877-1878): Yatan hastalarda görülen enfeksiyonlar ve mortalite oranları. Türk Mikrobiyoloji Cem Derg 2019;49:104112. https://dx.doi.org/10.5222/TMCD.2019.104

21. Münir A. Yeni Askeri Hıfzıssıhha. İstanbul Mekteb-i Harbiye Matbaası, 1340 (Rumi). 